doi: $10.15503 /$ jecs2021.1.479.503

\title{
A LESSON DESIGN ON THE SUBJECT OF LOCAL CUISINE AS A COURSE UNIT IN LAN- GUAGE TEACHING
}

\author{
HASAN COŞKUN \\ Çankırı Karatekin University, Faculty of Letters, \\ Department of Education, Fatih Mahallesi, \\ Uluyazı Kampüsü Ring Yolu, 18100 Çankırı, Turkey \\ E-mail address: hcoskun1952@gmail.com \\ ORCID: https:/ / orcid.org/0000-0002-8112-1677
}

\begin{abstract}
Aim. In Turkey, German ranks second after English as a foreign language in private courses, schools, and universities. There is an important relation between the selection of the subject of German courses, i.e., the detailed planning of the courses, and the implementation of the appropriate method. In this research, the subject of cuisine was planned for teaching German at universities. The purpose of this research is the preparation, implementation and evaluation of a sample lesson focused on the selection of the subject of cuisine for German courses taught in the universities.

Methods. This research on cuisine was qualitative in nature. The document analysis technique was used in the research (Kuş, 2007; Yıldırım \& Şimşek, 2008). During the 2018/2019 academic year the researcher taught on the subject of cuisine selection in his German courses. The implementation and evaluation of the subject of cuisine are developed by Hasan Coşkun (2020) in accordance with the lesson planning model previously prepared. The materials used in this lesson are prepared according to the model developed by Coşkun (2020). The unit on cuisine has been revised for this article.

Result and Conclusion. The success of the lesson planning model mentioned in this article was also observed in the activities conducted earlier. It was also seen that the students who attended German courses in connection with education or work in Germany, Austria, and Switzerland exerted efforts in establishing contact with the instructor and with other students attending the class. It was observed that participants talked about the Turkish, German, and Chinese cuisine in their families, peer groups, restaurants, and snack bars. In addition to the subject discussed in the class, the method implemented in the lesson and the planning of the course according to the method, play an important role in the continuation of the students' interest. Therefore, effective lesson planning models should be developed. This lesson model is also applicable to other languages.

Originality. German is offered as a foreign language in Turkish schools in the second grade. Consequently, German is usually chosen as a second foreign language after English. Students from all the departments of the university may attend the elec-
\end{abstract}


tive German language classes to study or work in Germany. The condition for participation in the courses "German for Erasmus" and "German for Communication," taught by the researcher, aims to prepare the students to read and speak German at the A2 level. It is frequently observed that the participants speak German at different levels. The overseas experience of the participants, the level of their German and their knowledge of other languages play an important role in this respect. In recent years, the number of course participants from Germany and other countries have increased. The students who had been in German speaking countries within the Erasmus program participate in German courses to maintain their fluency in the German language. To conduct the courses effectively, a suitable method should be developed and such an approach will help the participants who come from different countries and students with different levels of fluency. It is believed that this inter-disciplinary research will contribute to the use of the active method during German lessons.

Key words: cuisine, restaurant, lesson planning, development of teaching materials

\section{INTRODUCTION}

$\mathrm{D}$ uring the times of the Ottoman Empire (1299-1918), Arabic and Persian were important foreign languages in the Ottoman schools. After the proclamation of the Republic of Turkey in 1923, the national aim was to impede the influence of Arabic and Persian on the Turkish language. Since the proclamation, English, German, French, Russian, Chinese, Japanese, and other languages have been offered as foreign language courses in the educational institutions. In the last ten years, Arabic has been more increasingly offered as a foreign language. The common religion of Islam, commercial relationships with Arab countries, and Turkey's role in the Middle East have all contributed to this.

The European Union recommends that at least two foreign languages should be taught in the member states of the European Union. To support the realization of this project, the Common European Framework of Reference for Languages was developed. This framework was also translated into Turkish. The language books and teaching materials were written and developed based on this framework. This framework was also used in the revision of the teacher training programs, (Coşgun-Ögeyik, 2009) yet foreign language learners in Turkey are not at the desired level.

To increase the success in foreign language teaching, the following measures are proposed:

- Contemporary methods in teacher training and school teaching

- Development of schoolbooks based on the new language acquisition theories

- Foreign language lessons at the elementary school

- Promotion of student exchanges

- Small school groups

- Application of new technologies

- Better job prospects for employment. 
At this point, the position of cuisine in publications should be taken as reference. The theme of cuisine is published in daily newspapers, brochures, magazines, dictionaries, textbooks, and broadcasted in TV programs. In the book English for Tourism (Yorganc1 \& Keskil, 2008, pp. 117-147) the topic of cuisine is dealt with under the following headings "Cuisine Services Management," "Food and Beverage Services Management", and "The Principles of Nutrition and Menu Planning." In the book Otelcilik ve Turizm Alanında Öğretim [Teaching on Hotels and Tourism], the topic of cuisine is dealt with in detail in several articles (Demirezen, 2013; Coşkun, 2013). In the dictionary published in Austria (Österreichisches Standarddeutsch , 2014, pp. 44-49) titled Basiswörterbuch Türkisch - Deutsch/Deutsch -Türkisch Vokabeln und Phrasen für den Alltag, the words in the field of cuisine in connection with the topic of shopping are listed under the following subtitles:

Table 1

Topics related to cuisine

\begin{tabular}{lll}
\hline Food and beverages & Cereal products & Dairy products \\
\hline Meat, fish, and sausages & Spices and herbs & Fruit \\
\hline Vegetables & Meals & \\
\hline Source: own research. &
\end{tabular}

The cuisine as a topic is handled in detail under the heading Food and beverages in the books related to tourism (Wehmeier, Dralle, \& Thiergart, 2015). The school vocabulary contains extensive lists of food, cooking methods, and meals (Häublein \& Jenkins, 2008).

The topic of cuisine is also handled in language books. The course book titled Topics is given here as an example (Aufderstraße, Bock, Gerdes, Müller, \& Müller, 1993). Both the teachers and the academics can didactize the topic of cuisine in relation to the target group, using the literature. This article explains how the topic of cuisine is used to teach the German courses in 13 steps (Coşkun, 2018; Karabıyık, 2018). The process is based on the teaching model and didactized by the researcher.

\section{METHOD}

The study was conducted through the qualitative method (Kuş, 2007; Yıldırım \& Şimşek, 2008). Initially, a draft for the class in collaboration with teachers is developed, consulting the university graduates as experts. In this study, the literature related to language teaching and the documents prepared by the researcher are used. Additionally, the discussions are held with the expert teachers, university graduates, and the students. In the course, the researcher principally works according to his own model with a key word that presents the topic and 24 words that are often used in relation to the topic. A picture of the lunch in the Community of Yapraklı was selected as the key word. Then five 
Turkish sentences related to this picture were written. The Turkish sentences were then translated into German and English (Coşkun, 2018).

The cuisine theme has been discussed on various occasions over the past ten years. Various materials have been developed in German and tested for every occasion. These German materials were discussed with a German teacher at the Goethe Institute in Ankara and with a German teacher in Lüneburg (Germany). Most recently, a master's degree student developed a teaching unit as part of field research supported by the Konrad-Adenauer-Foundation in the Yaprakl1 community (Ersan, 2020). This article utilizes some of the texts from this unit.

\section{GENERAL INFORMATION}

There are several factors that influence teaching. Therefore, every lesson plan should aim at a specific target group, and certain general information should be mentioned. These are, for example, educational institutions, branch of instruction, subject, and duration.

- Target Group: Students of German courses at the university

- Name of the lesson: German for Communication

- Topic: Cuisine in Yaprakli

- Duration: 80 minutes (2 class hours)

\section{RATIONALE OF THE LESSON}

In the introduction it was pointed out that the topic of cuisine is mentioned, for example, in daily newspapers, brochures, magazines, dictionaries, textbooks, and TV programs. Two publications are referred to in this section.

The German textbook einFach gut, which has been adapted for the Czech Republic, Hungary and the Baltic States and which was developed for vocational schools, deals with the topic "Cooking" in Unit 9 on 3 pages. It starts with the following subtitle: "The appetite comes while eating/Also on imperatives and infinitives." There are two sentences under this subtitle: "Hedgehog named Alfred only eats organically! What is he eating?" (Glowacka-Perlowska, Lipczynska, Ludwin, Luniewska, Pietrowska, Rozwalka, Szczepanska, Tworek, Wasik \& Zagórna, 2007, pp. 107-108). Then the students work on a recipe for ingredients and on verbs as follows.

Hedgehog Alfred wants to cook a potato soup.

What ingredients does he need?

What does he have to do with them?

- Heat the butter, add the onions and chives.

- Steam the potatoes and then sprinkle flour.

- Add the leek and spinach by using the stock cube dissolved in 1 liter of water, and turn off the heat.

- Stir and bring to the boil.

- Season with pepper, salt, and nutmeg, cook for about 30 minutes (Glowacka-Perlowska et al., 2007, pp. 107-108). 
Finally, the following homework is given: "Your pen pal in Germany wants to cook a specialty from the Czech Republic/Slovakia. Write him a recipe using infinitives and imperatives" (Glowacka-Perlowska et al., 2007, pp. 107-108). In an English language book on tourism (Mitchell, 2008, pp. 63-76), there is a detailed chapter on the subject of food.

\section{CUISINE CULTURE OF THE COMMUNITY OF YAPRAKLI}

The food culture in the district is briefly described here. Food culture is one of the important features of the region in question. Food has many different functions in Yaprakli Community. Food provides social love, respect, solidarity, and integration. Some meals are cooked for special occasions, some to convey a message, and some to help. While dishes made for a wedding house increase joy and happiness, meals taken to the funeral home reduce pain.

The food brought by family friends who share the struggle do not only feed people. These meals are taken to the funeral home so that family members also feel that they are not alone and that they are loved in difficult days. Those who cook for the funeral home find that they bring happiness and peace to their suffering friends. The sorrow is replaced by hope. Meals for breaking the fast are served during Ramadan, Circumcision and to the family members who are sending their sons to the military. In the cuisine of the Yaprakl1 Community meals containing meat, cereals, and vegetables are common. Pastries also have an important place in the community. The most common dishes which consist of desserts, marmalades, pickles, and drinks are:

- Food: Yogurt meal, rice with meat, rice, milk soup, soup made of flour, tomatoes and onions, yogurt soup, casserole, stuffed leaves with meat or olive oil, thin triangular-shaped flaky pastries, dried pickled vine leaves, green beans, aubergine, pepper, tomato and pepper paste, homemade pasta (vermicelli), noodle soup, nip dough, minced meat and flaked roasting, rock salt, cheese in form of an earthenware jug, bulgur, chop, crackling, roasted beans, wheat semolina, flour soup, roasted chick-peas, dough clot with thickened grape must, wheat semolina in boiler, and mushroom.

- Pastries: Round flat loaf unleavened, thin bread, thin amulet-shaped bread, coarse dough, ingot bread bars, pan bun, walnut pâté, thin flatbread, muffin with oily inside and pancake.

- Desserts: Baklava, halva, shredded dough baked in syrup topped with crushed nuts.

- Marmalades: Roasted and ground wheat pear, rosehip marmalade.

- Pickles: Hyssop, wild pear, fickle, parsley, dill, long doughnut in syrup, cherry syrup.

- Garnish: mint, parsley, dill, long doughnut in syrup, cherry syrup, cranberry sour, rack, tear-thumb, herb.

- Drinks: Tea, buttermilk, compote, syrup of cornelian cherry, plum fruit leather.

- Salt: Rock salt. 
Yapraklı community has a rich cuisine. The cuisine of Yapraklı community should be promoted at national and international level (Ersan, 2020; Demiröz, 2017).

\section{THE OBJECTIVES OF THE LESSON}

The lessons are generally prepared, carried out, evaluated, and further developed based on the existing curriculum. The formulation of teaching or learning objectives is an elementary instrument in all curricula. They serve as instructions for teaching staff and textbook authors and should create transparency in the educational establishment and help control the learning process through the correct dosage of input. The focus on competencies is an example of this change of perspective. The teacher should investigate the question of which teaching or learning objectives are decisive for the lesson and how they can be used in a system of teaching/learning and teaching management for quality development and quality assurance.

In the literature, a distinction is made between guideline teaching goals (guiding goals), rough teaching goals, and detailed teaching goals.

The guiding teaching objectives (guiding objectives) represent the fundamental pedagogical and educational policy objectives that a society and its educational institutions consider important. In the general teaching objectives, these are tailored to the institutional framework of the relevant school system according to relevant subject-specific and pedagogical criteria. The general teaching goals are finally specified and put into operation in the detailed teaching goals for the skill areas. The skill areas are grammar, reading, writing, listening, and speaking (Roche, 2013).

\section{EXPLANTATION OF THE KEYWORD AND THE 24 WORDS USED}

Hölscher, et al. (2006) formulate the meaning of vocabulary for language acquisition as follows:

In the beginning there was the word, it is not only said in the Bible. The key to language acquisition is word acquisition. There is no grammar without words. The grammar can only emerge from the words, namely only when several words are to be combined sensibly. In addition, it is human nature to conceptualize the world. We start from the thesis: "Give the students vocabulary, they will find the grammar on their own!

The authors cited above point out that vocabulary acquisition can be expanded playfully and with demonstrable success. At the same time, they write that the expansion of the vocabulary takes place in learning scenarios. Based on the above-mentioned thesis and function of the words as well as the learning scenarios, I use 24 other words in my foreign language learning model that are 
closely related to the topic. In addition to the use of these words, dialogues, reading texts and various exercises are being worked on (Coşkun, 2018).

\section{Table 2}

Flash card for Cuisine

The key word and the 24 words used in the lesson Yöresel Mutfak / die lokale Küche/ Local Cuisine

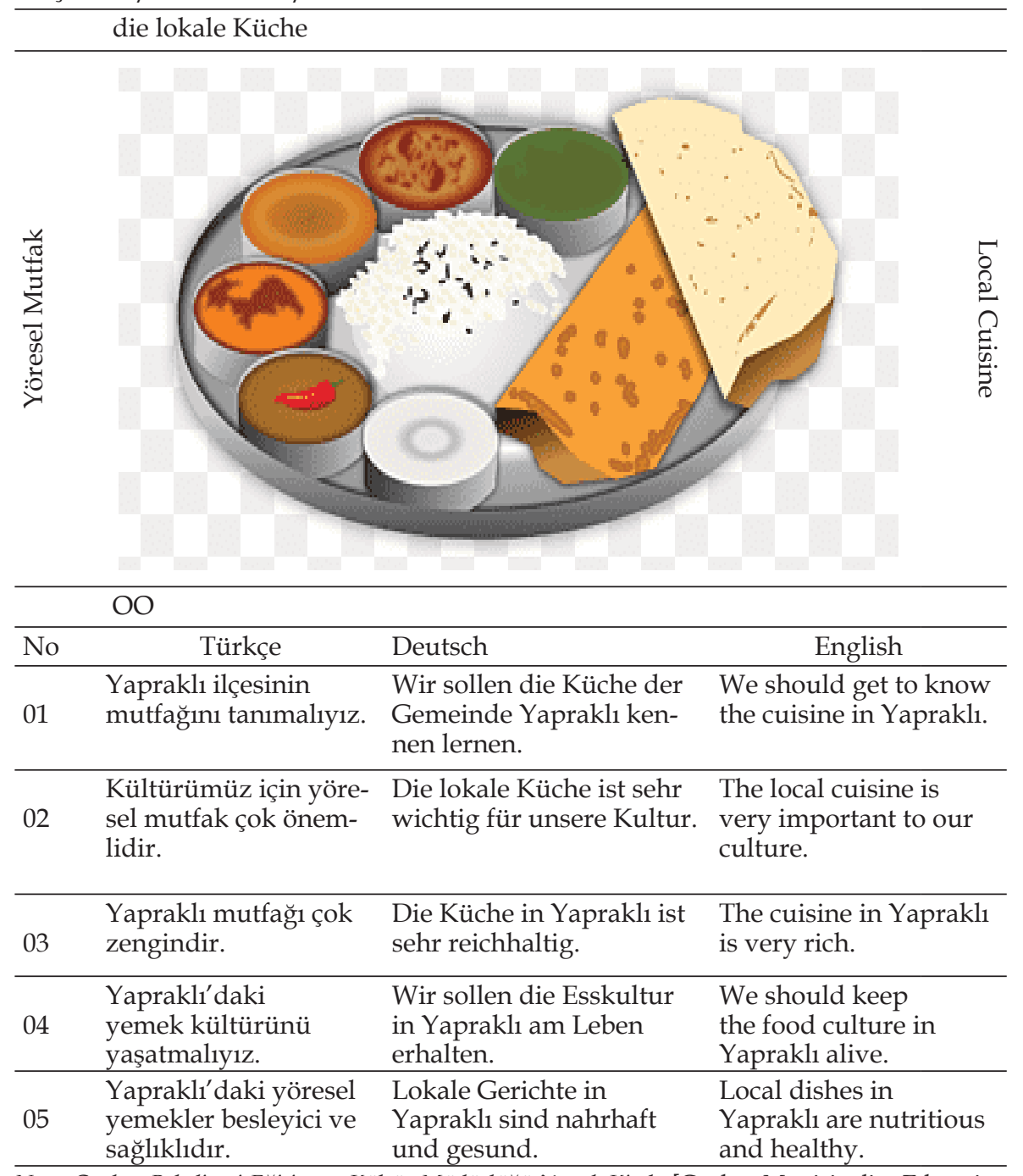

Note: Cankırı Belediyesi Ĕ̈itim ve Kültür Müdürlüğü Yemek Kitabı [Çankırı Municipality Education and Culture Directorate Cookbook], Ersan, 2020, revised by Coşkun, 2021.

Source: own research. 
Table 3

The first group of words for Local Cuisine

Sözcük Listesi / Wortliste / Word List / Yöresel Mutfak / Lokale Küche / Local Cuisine (a)

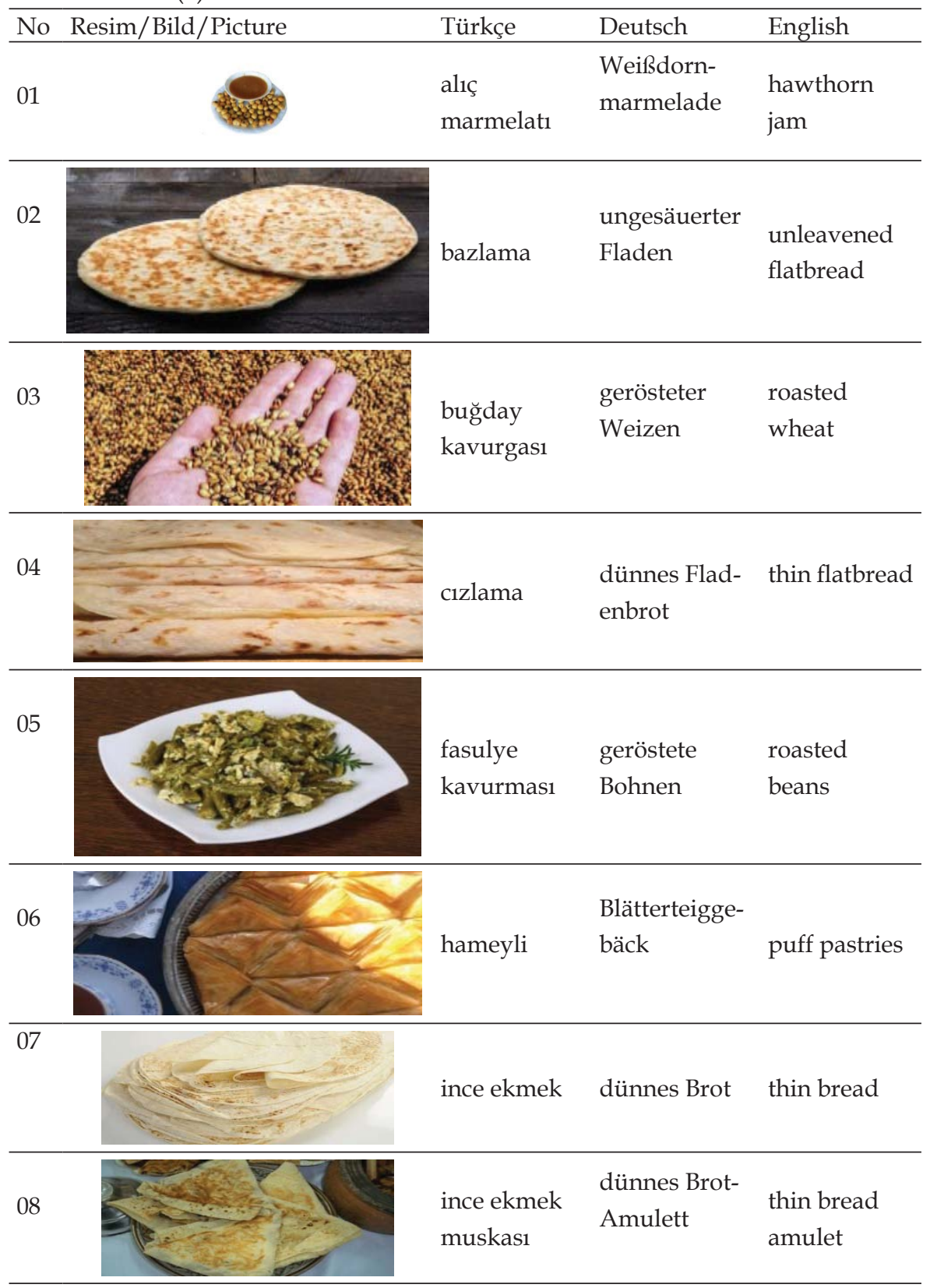




\begin{tabular}{|c|c|c|c|}
\hline 09 & iri hamur & grober Teig & coarse dough \\
\hline 10 & kaya tuzu & Steinsalz & rock salt \\
\hline 11 & keşkek & Weizengrieß & $\begin{array}{l}\text { wheat } \\
\text { semolina }\end{array}$ \\
\hline 12 & $\begin{array}{l}\text { kızılcık } \\
\text { şurubu }\end{array}$ & $\begin{array}{l}\text { Kornel- } \\
\text { kirschensirup }\end{array}$ & $\begin{array}{l}\text { syrup of } \\
\text { cornelian } \\
\text { cherry }\end{array}$ \\
\hline
\end{tabular}

Source: own research.

Table 4

The second group of words for Local Cuisine

Sözcük Listesi / Wortliste / Word List / Yöresel Mutfak / Lokale Küche / Local Cuisine (a)

\begin{tabular}{|c|c|c|c|c|}
\hline & Resim/Bild/Picture & Türkçe & Deutsch & English \\
\hline 13 & & $\begin{array}{l}\text { kuşburnu } \\
\text { marmelatı }\end{array}$ & $\begin{array}{l}\text { Hagebutten- } \\
\text { marmelade }\end{array}$ & rosehip jam \\
\hline 14 & & külçe & Walnussbrot & $\begin{array}{l}\text { walnut } \\
\text { bread }\end{array}$ \\
\hline 15 & & $\begin{array}{l}\text { küpecik } \\
\text { peyniri }\end{array}$ & Tonkrugkäse & $\begin{array}{l}\text { clay jug } \\
\text { cheese }\end{array}$ \\
\hline 16 & & $\begin{array}{l}\text { nohut } \\
\text { kavurması }\end{array}$ & $\begin{array}{l}\text { geröstete } \\
\text { Kichererbsen }\end{array}$ & $\begin{array}{l}\text { roasted } \\
\text { chickpeas }\end{array}$ \\
\hline 17 & & pihtı & Teigklumpen & $\begin{array}{l}\text { lumps of } \\
\text { dough }\end{array}$ \\
\hline
\end{tabular}




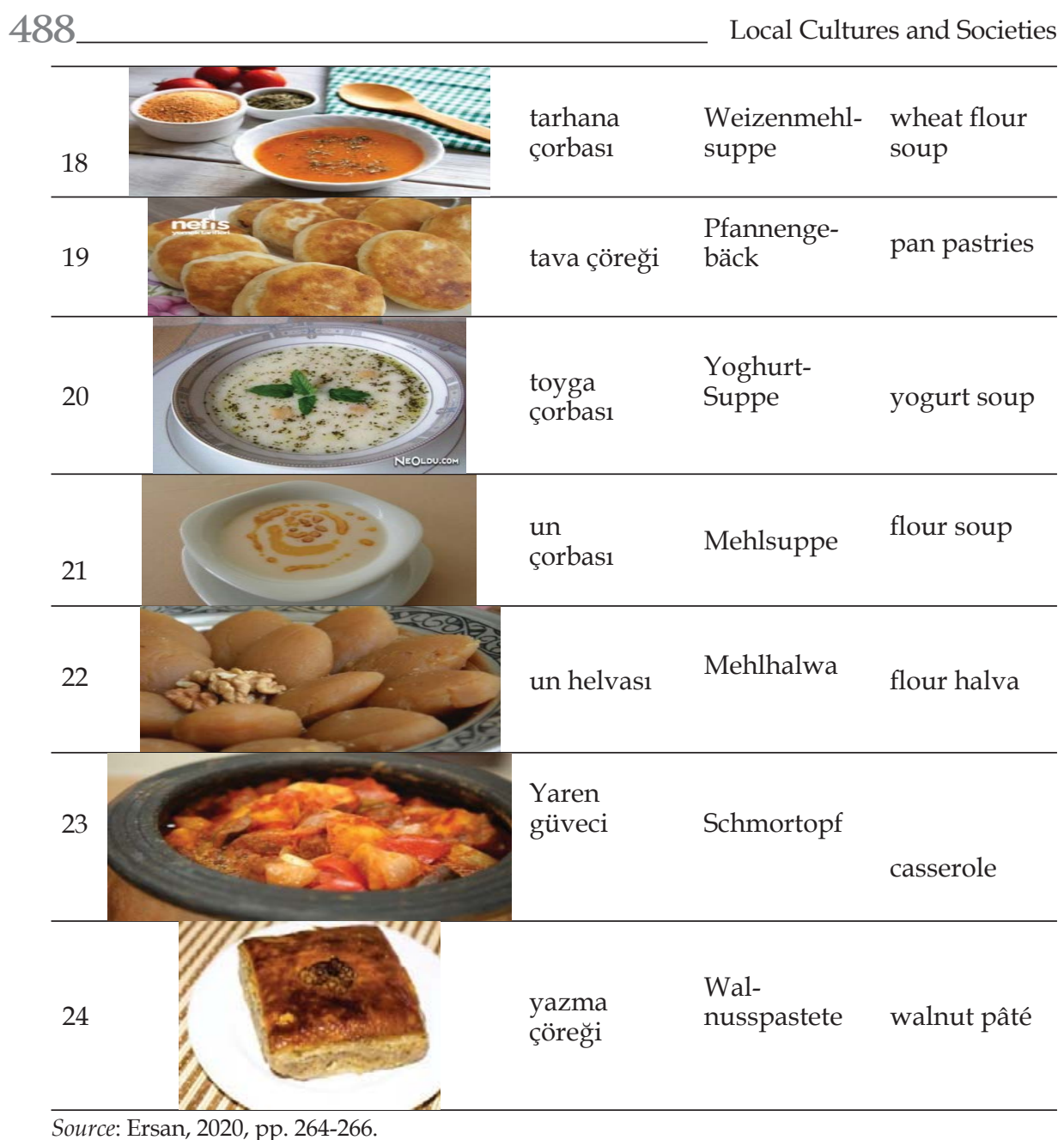

Source: Ersan, 2020, pp. 264-266.

Dialogue (Role holders: Emine (Mother), Hans (Father), Jeny (Grandmother), Mert, Buğra, Angelika)

Teacher: Today I brought a dialogue text. Six students will read the text of the dialogue.

Will those who want to volunteer come to the blackboard?

What is Yapraklı famous from?

\section{Part I}

\begin{tabular}{l|l|l}
\hline 01 & Angelika & Mother! I have homework. Can you help me? \\
\hline 02 & Emine & I love roasted wheat. \\
\hline 03 & Angelika & I have to learn more about the local cuisine in Yapraklı. \\
\hline 04 & Emine & $\begin{array}{l}\text { We live downtown. Actually, we are from Yapraklı. I make } \\
\text { very good flatbread. }\end{array}$ \\
\hline
\end{tabular}




\begin{tabular}{c|l|l}
\hline 05 & Angelika & You are right. I could not remember. What is a thin flatbread? \\
\hline 06 & Emine & $\begin{array}{l}\text { You can do your homework with your grandmother. Your } \\
\text { grandmother knows the benefits of rock salt very well. }\end{array}$ \\
\hline 07 & Angelika & Ok, mommy. I will also ask about the bean roast. \\
\hline 08 & Mert & What are you doing, Angelika? \\
\hline 09 & Angelika & $\begin{array}{l}\text { I'm doing my homework with my grandmother. I hope she } \\
\text { made thin bread. }\end{array}$ \\
\hline 10 & Buğra & $\begin{array}{l}\text { May I learn the subject of the homework? Local cuisine? Puff } \\
\text { pastries are very common in Yaprakll. }\end{array}$ \\
\hline
\end{tabular}

\section{Part II}

\begin{tabular}{l|l|l}
\hline 11 & Angelika & $\begin{array}{l}\text { The food culture in Yaprakl is very rich. Coarse dough is } \\
\text { preferred. }\end{array}$ \\
\hline 12 & Buğra & $\begin{array}{l}\text { Interesting subject! We can help you. Have you heard of the } \\
\text { thin bread amulet? }\end{array}$ \\
\hline 13 & Angelika & $\begin{array}{l}\text { Grandma! Can you help me with my homework? For } \\
\text { example, how to make wheat semolina? }\end{array}$ \\
\hline 14 & Mert & $\begin{array}{l}\text { Grandma, Angelika's homework is about the food culture of } \\
\text { our county. Do you know syrup of cornelian cherry? }\end{array}$ \\
\hline 15 & Buğra & What dishes were cooked in the past? \\
\hline 16 & Grandmother & $\begin{array}{l}\text { Let's see, sit with me. I will also give information about } \\
\text { rosehip jam. }\end{array}$ \\
\hline 18 & Angelika & $\begin{array}{l}\text { Our teacher asked us to bring a local meal to school. Should I } \\
\text { bring some bar bread to school? }\end{array}$ \\
\hline 19 & Emine & $\begin{array}{l}\text { It would be great! Do not forget to take the clay jug cheese } \\
\text { with you. }\end{array}$ \\
\hline 20 & Grandmother & $\begin{array}{l}\text { Would you recommend the flour soup as well? First, I want } \\
\text { to tell you how flour soup is made. }\end{array}$ \\
\hline
\end{tabular}

\section{Part III}

\begin{tabular}{|c|c|c|}
\hline 21 & Mert & Grandma, I love the walnut pâté from pastries. \\
\hline 22 & Grandmother & Wheat flour soup is a dish unique to our region. \\
\hline 23 & Angelika & Do you know how pan pastries are made? \\
\hline 24 & Grandmother & I know. I also make very good yogurt soup. \\
\hline 25 & Buğra & $\begin{array}{l}\text { Grandma, we made flour halva for the village together when } \\
\text { we were little. Shall we make flour halva today? } \\
\end{array}$ \\
\hline 26 & Angelika & $\begin{array}{l}\text { Casserole is an important symbol of our culture. Do you know } \\
\text { the recipe? }\end{array}$ \\
\hline 27 & Grandmother & Yes, I know it very well. \\
\hline 28 & Hans & I also make very good walnut pâté. \\
\hline 29 & Grandmother & $\begin{array}{l}\text { We always use rock salt in our meals. But salt is not put in } \\
\text { hawthorn jam. }\end{array}$ \\
\hline 30 & Angelika & $\begin{array}{l}\text { Thank you so much. I took notes of what you said. I will } \\
\text { share it with my teacher and friends. We will start writing the } \\
\text { recipes. }\end{array}$ \\
\hline
\end{tabular}

Source: Ersan, 2020, p. 267, revised by Coşkun, 2021. 


\section{READING TEXT}

Food Culture of Our Community

Read this text and answer the questions.

1. Anatolia is known as a wheat storage of Turkey. Sowing the seed, giving spike, forming wheat grains and making flour from wheat is a production process. Each stage requires some effort. In the Central Anatolia region, where mainly wheat and legumes are cultivated, unleavened flatbread based on grain, roasted wheat, thin flatbread, thin bread and large dough are made by the Community of Yapraklı. Local foods, especially when cooked at home style are additive-free and natural food sources. Therefore, local foods are preferred.

2. There are seven geographical regions in Turkey. For example, instead of the East and Southeast Region, it is called the East region. Yapraklı community is located at the intersection of the Black Sea Region and Central Anatolia Region. Walnut bread, pan pastries, and roasted beans are common in the region. Since animal husbandry is also carried out in Yaprakll, it is known that meat dishes such as casserole are made in addition to clay jug cheese.

3. The community of Yapraklı has hosted various civilizations. For this reason, the food culture in Yapraklı region has remained under the influence of settled and nomadic societies on one hand and the Black Sea and Central Anatolia Regions on the other. Flour soup, wheat flour soup, yogurt soup, roasted chickpeas, and lumps of dough are served in the region. Relations with neighboring countries, internal and external migration, and tourism are also important factors in the variety of food in Anatolia. It can be said that Arab countries are famous for sweet and bitter dishes whereas neighbors in the Aegean region are famous for their salads and fast food and France and Germany are famous for their cakes.

4. Various vegetables and fruit products are also grown in by the community of Yaprakl. There are lakes and streams in the zone of the community Yapraklı. Therefore, hawthorn jam, rosehip marmalade and syrup of cornelian cherry are made. In the region there is also thin bread amulet on the table. Widely, different salads enrich the food culture. Fish is also consumed in the regions close to the sea. Various vegetable dishes such as corn soup, stuffed cabbage, artichoke with olive oil, and stuffed squashed blossoms are common. It is seen that products such as milk, meat and cereals are frequently used in meals in Central Anatolia, Eastern, and Southeastern Anatolia Regions.

5. 5. There are various underground mines such as lignite coal and copper in Yaprakl1. Rock salt is also extracted in the region. In the region, flour halvah is also widely made in addition to puff pastries, walnut pâté, and pan pastries. The people of two villages in the community of Yapraklı have intensive relations with France. The effect of these relations on Yapraklı cuisine culture should be investigated. In addition, it should be examined whether Yapraklı cuisine was brought to France. As a result of the labor migration, bagel, lahmacun and döner kebab are widely consumed abroad (Ersan, 2020, p. 268, revised by Coşkun, 2021). 


\section{THE IMPORTANCE OF THE EDUCATIONAL GAME}

There are different definitions of the term game (Parmentier, 2004, p. 929; Bakırcıoğlu, 2016, p. 1141). The old definition of the game by the Dutch cultural anthropologist Johan Huizinga is often referred to. The definition in his main work Homo ludens is as follows:

Play is a voluntary act or activity that is carried out within certain fixed limits of time and space according to voluntarily accepted but absolutely binding rules, has its goal in itself and is accompanied by a feeling of tension and joy and awareness of 'being different' than 'ordinary life.' (Huizinga, 2004, p. 37)

It is now played in the family, at school and in leisure time. There is a large gaming industry that is accompanied by science. Game science differentiates between purposeless and purposeful games. Purposeless games are functional games. Purposeful games are educational games. The educational game serves the purpose of learning. Play is a form of activity. The verb to play is also an activity. This activity can be carried out for pleasure, for relaxation, just for the joy of doing it, but also as a job. In the last context, theatrical performances, sports games, and playing the violin are given as examples.

The game is an occupation that is often undertaken as a playful confrontation with other members of the community. Much of the cognitive development and the development of motor skills and social competence takes place through games. This applies to both humans and numerous animal species. Therefore, the game is of great importance for pedagogy.

In pedagogy, gaming is also used specifically as a learning method. This learning method is also widespread in foreign language teaching. A game is often based on very specific courses of action. Binding rules can emerge from these courses of action, especially in the community. The concrete course of action can result from the type of game itself, the rules of the game (dodgeball), as well as from the desire of different individuals to act collectively (building a sand castle) (https://de.wikipedia.org/wiki/Spiel). There is a wide variety of games. Their number is not limited as games are constantly being reinvented and varied. The caste educational game was developed for this lesson.

\section{INSTRUCTIONS OF THE CASTE EDUCATIONAL GAME}

Educational caste games are often used to make lessons more attractive. It is important that the rules of the educational game are clearly formulated and that appropriate material is developed. For this lesson unit, I designed the caste educational game. I improvised the word box from the Indian caste system. The playing area for the caste learning game is divided into 25 castes. Below you can see the template and the 25 rules. 


\begin{tabular}{|c|c|c|c|c|c|c|}
\hline 16 & 17 & \multicolumn{3}{|c|}{18} & 19 & 20 \\
\hline 15 & 04 & \multicolumn{3}{|c|}{05} & 06 & 21 \\
\hline \multirow{3}{*}{14} & \multirow{3}{*}{03} & \multicolumn{3}{|c|}{ die Küche } & \multirow{3}{*}{07} & \multirow{3}{*}{22} \\
\hline & & $\begin{array}{l}\frac{y}{\widetilde{J}} \\
\stackrel{\mathbb{E}}{\Xi} \\
\sum\end{array}$ & $\begin{array}{c}\text { KEY } \\
\text { WORD }\end{array}$ & & & \\
\hline & & \multicolumn{3}{|c|}{00} & & \\
\hline 13 & 02 & \multicolumn{3}{|c|}{01} & 08 & 23 \\
\hline 12 & 11 & \multicolumn{3}{|c|}{10} & 09 & 24 \\
\hline
\end{tabular}

Fig 1. Template for the Educational Caste Game Source: own research.

1. The caste educational game is played with 25 cards and one dice.

2. The playing field also uses a base (pad) divided into 25 castes $(8 \times 8 \mathrm{~cm})$ and four word- sentence lists.

3. The caste in the middle of the pad is for the card with the keyword.

4. Target group: from 3rd class onwards.

5. Duration: Depending on the target group, 15-20 minutes.

6. The participants are divided into groups of five.

7. One participant is the referee.

8. The other four participants are individual players.

9. The four participants sit at a square table.

10. The referee finds a place near the game table.

11. The game organization gives each referee a package with the game accessories.

12. Each referee puts the paper, 25 cards, the four word-sentence lists, the dice, and the sheet of paper with the instructions of the game on the table.

13. Each referee reads the rules of the game aloud.

14. Each referee places the card with the keyword in the center of the pad (board).

15. Whoever rolls the highest number starts the game. 
16. The order of play is clockwise.

17. If the first player throws a six, they choose a card, read the number on the card in both Turkish and German, and roll again.

18. If they throw a six again, they choose a card again, read the number, the Turkish and German words on the card, and enter the words in the number column of the word-sentence list. Then they roll again and repeat the same action.

19. If they don't roll a six anymore, they give the dice to the player on their left.

20. The new player does the same thing.

21. After $\mathbf{1 5}$ minutes the game stops.

22. Each player reads out the numbers and the Turkish, German and English words.

23. All players are applauded.

24. The game will continue until the end of the agreed time.

25. The referees report on the result in plenary.

Note: Depending on the target group, the game organizer may request the formation of sentences with respective words. Participants can write texts from the sentences.

\section{MATERIALS TO BE USED FOR THE CASTE EDUCATIONAL GAME}

Dietmar Rösler and Nicola Würffel (2014) use the example of German lessons to distinguish between learning materials and media. The term learning material refers to all materials that can be used by learners to learn German. Learning materials can be textbooks, texts, images of all kinds, games, films, etc. But there are also learning materials such as newspaper articles, radio programs, etc. that are used for language lessons. The term media has many definitions. Media are means by which content, tasks etc. are transported in order to support the acquisition of knowledge and skills. At this point, special media should also be mentioned. There are three main reasons for this:

- Social media opens up new possibilities to promote joint writing, to train listening and listening comprehension as well as oral communication.

- With their publication options, social media can motivate learners to write linguistically understandable and interesting texts.

- Social media can support mobile learning (Rösler and Würffel, 2014, p. 172).

For an attractive teaching it is important that the teacher uses different materials and media in the class.

The educational caste learning game package contains the following parts: a sheet of paper with the rules of the game, a base $(30 \times 30 \mathrm{~cm}), 25$ cards $(8$ $x 8 \mathrm{~cm}$ each), four word-sentence lists, a dice. One of the cards symbolizes a kitchen theme. The kitchen is the key word. This card has the number 00. The other 24 cards symbolize the 24 dishes from the word list. All 25 cards are labeled in Turkish, German and English. On each card there is an image that symbolizes the respective word. 
Table 5

The flow chart of the lesson Local Cuisine

\begin{tabular}{|c|c|c|c|c|c|}
\hline Step & $\begin{array}{l}\text { Dura- } \\
\text { tion } \\
\text { (min.) }\end{array}$ & Teacher Behaviour & Student Behaviour & $\begin{array}{l}\text { Tech- } \\
\text { nique / } \\
\text { Method }\end{array}$ & Materials \\
\hline 1 & $\begin{array}{c}6 \\
\min .\end{array}$ & $\begin{array}{l}\text { The teacher shows a } \\
\text { video of the cuisine } \\
\text { in the community of } \\
\text { Yaprakli. He/she asks } \\
\text { the students what they } \\
\text { know about this food. } \\
\text { The teacher announces } \\
\text { the subject of the cui- } \\
\text { sine in Yapraklı. }\end{array}$ & $\begin{array}{l}\text { The students say what } \\
\text { they know about food. } \\
\text { A student writes the } \\
\text { nouns such as soup, } \\
\text { bread, meat and milk on } \\
\text { the board. } \\
\text { The other students } \\
\text { form similar sentences. }\end{array}$ & $\begin{array}{l}\text { Question } \\
\text { answer }\end{array}$ & $\begin{array}{l}\text { Video } \\
\text { Black } \\
\text { board } \\
\text { Projector }\end{array}$ \\
\hline 2 & $\begin{array}{c}6 \\
\text { min. }\end{array}$ & $\begin{array}{l}\text { The teacher shows } \\
\text { different images on } \\
\text { cuisine and asks what } \\
\text { the participants think } \\
\text { about the images. } \\
\text { The teacher asks: Shall } \\
\text { we go out to eat today? }\end{array}$ & $\begin{array}{l}\text { The students discuss } \\
\text { the images reflected } \\
\text { on the wall. These are } \\
\text { local foods. } \\
\text { Yes, we're going to eat } \\
\text { together today. }\end{array}$ & $\begin{array}{l}\text { Oral } \\
\text { state- } \\
\text { ment }\end{array}$ & Images \\
\hline 3 & $\begin{array}{c}10 \\
\text { min. }\end{array}$ & $\begin{array}{l}\text { The teacher asks the } \\
\text { students to hang the } \\
\text { flash cards. } \\
\text { The teacher stretches } \\
\text { the clothesline in the } \\
\text { classroom. He/she } \\
\text { gives those in the front } \\
\text { row } 25 \text { flash cards } \\
\text { about the cuisine, } \\
25 \text { clothes pegs, and } \\
\text { clothesline instructions } \\
\text { enough for groups of } \\
\text { two. }\end{array}$ & $\begin{array}{l}\text { The students hang } \\
\text { the flash cards on the } \\
\text { clothesline in pairs. }\end{array}$ & $\begin{array}{l}\text { Group } \\
\text { work }\end{array}$ & $\begin{array}{l}\text { Clothes- } \\
\text { line. } \\
25 \text { flash } \\
\text { card, } \\
25 \text { clothes } \\
\text { pegs } \\
\text { clothesline } \\
\text { instruc- } \\
\text { tions }\end{array}$ \\
\hline 4 & $\begin{array}{c}6 \\
\text { min. }\end{array}$ & $\begin{array}{l}\text { The teacher asks for } \\
\text { the flash cards, clothes } \\
\text { pegs, and the clothes- } \\
\text { line to be collected and } \\
\text { given to the class lead- } \\
\text { er. The teacher asks the } \\
\text { group leaders to give } \\
\text { him the materials. }\end{array}$ & $\begin{array}{l}\text { The students give the } \\
\text { flash cards, clothes } \\
\text { pegs, and the clothes- } \\
\text { line to the group lead- } \\
\text { ers. The group leaders } \\
\text { return the material to } \\
\text { the teacher. }\end{array}$ & $\begin{array}{l}\text { Individu- } \\
\text { al work }\end{array}$ & $\begin{array}{l}25 \text { flash } \\
\text { cards, } \\
25 \text { clothes } \\
\text { peg } \\
\text { clothesline, } \\
\text { yogurt } \\
\text { cups }\end{array}$ \\
\hline 5 & $\begin{array}{c}10 \\
\text { min. }\end{array}$ & $\begin{array}{l}\text { The teacher says that he } \\
\text { brought up a dialogue. } \\
\text { He wants six students } \\
\text { to come to the board } \\
\text { and read the dialogue. }\end{array}$ & $\begin{array}{l}\text { Six students come to } \\
\text { the board and read the } \\
\text { dialogue. }\end{array}$ & read out & $\begin{array}{l}\text { Dialogue } \\
\text { text }\end{array}$ \\
\hline
\end{tabular}




\begin{tabular}{|c|c|c|c|c|c|}
\hline 6 & $\begin{array}{l}10 \\
\min .\end{array}$ & $\begin{array}{l}\text { The teacher asks them } \\
\text { to share the ideas re- } \\
\text { lated to the dialogue. }\end{array}$ & $\begin{array}{l}\text { The students share the } \\
\text { ideas they have made. }\end{array}$ & Class & \\
\hline 7 & $\begin{array}{l}20 \\
\text { min. }\end{array}$ & $\begin{array}{l}\text { The teacher announces } \\
\text { that he will be playing } \\
\text { the educational caste } \\
\text { game. He asks the stu- } \\
\text { dents to form groups } \\
\text { of five and distributes } \\
\text { the materials prepared } \\
\text { beforehand. }\end{array}$ & $\begin{array}{l}\text { The students thank the } \\
\text { teacher for the educa- } \\
\text { tional caste game and } \\
\text { form groups of five. } \\
\text { The game takes place } \\
\text { with the distribution } \\
\text { of materials. After the } \\
\text { game the students } \\
\text { share the results of the } \\
\text { group studies with the } \\
\text { other students. }\end{array}$ & $\begin{array}{l}\text { Group } \\
\text { work } \\
\text { and } \\
\text { presenta- } \\
\text { tion }\end{array}$ & $\begin{array}{l}\text { Materials } \\
\text { of educa- } \\
\text { tional caste } \\
\text { game }\end{array}$ \\
\hline 8 & $\begin{array}{c}10 \\
\text { min. }\end{array}$ & $\begin{array}{l}\text { The teacher asks the } \\
\text { students to form groups } \\
\text { of five and distributes } \\
\text { the texts written on } \\
\text { "cuisine in Yaprakll." } \\
\text { He asks the students } \\
\text { to create a word list } \\
\text { (German and Turkish) } \\
\text { with nouns, adjectives } \\
\text { and verbs. He asks the } \\
\text { students to answer the } \\
\text { questions related to the } \\
\text { text at home. }\end{array}$ & $\begin{array}{l}\text { The students form } \\
\text { groups of five and } \\
\text { examine the cuisine } \\
\text { distributed. } \\
\text { They create a word list } \\
\text { (German and Turkish) } \\
\text { with nouns, adjectives } \\
\text { and verbs. The stu- } \\
\text { dents write down the } \\
\text { homework. }\end{array}$ & $\begin{array}{l}\text { Group } \\
\text { work }\end{array}$ & $\begin{array}{l}\text { Reading } \\
\text { text } \\
\text { answer } \\
\text { sheet }\end{array}$ \\
\hline 9 & $\begin{array}{l}2 \\
\min .\end{array}$ & $\begin{array}{l}\text { The teacher summariz- } \\
\text { es the activity, thanks } \\
\text { the participants and as- } \\
\text { signs them homework } \\
\text { for the following week. }\end{array}$ & $\begin{array}{l}\text { The students take } \\
\text { notes while listening } \\
\text { to the teacher. They } \\
\text { thank the teacher for } \\
\text { the activity. }\end{array}$ & $\begin{array}{l}\text { Oral } \\
\text { state- } \\
\text { ment }\end{array}$ & \\
\hline
\end{tabular}

Total period: 80 minutes

Homework: The teacher wants each student to write five recipes for the next week and bring them to the class.

Source: own research.

\section{EVALUATION OF TEACHING}

The final stage of curriculum development is its evaluation. This stage determines the success of both the learner and the curriculum. The necessary changes are made based on the results of the evaluation of the curricula (Şeker, 2014). The same applies to the teaching units and individual lessons.

The evaluation takes place in three steps:

- Systematic collection of data

- Analysis of the collected data according to certain criteria

- Assessment of the results (Şeker, 2014). 
To evaluate the lessons, Karin Ende, Rüdiger Grotjahn, Karin Kleppin \& Imke Mohr (2013, p. 93) write: "Lessons cannot be planned continuously without the teacher repeatedly considering the learners and their skills and knowledge as a starting point to guess whether our learners have achieved the partial learning goals."

There are various options for evaluating the lesson: dictations, compositions (essays), tests, puzzles, etc. An observation and evaluation form has also been developed for this unit.

Table 6

Observation and Evaluation Form

\begin{tabular}{|c|c|c|c|c|c|c|}
\hline \multirow[b]{2}{*}{ No } & \multirow[b]{2}{*}{ Skills } & \multicolumn{5}{|c|}{ Degrees of Evaluation } \\
\hline & & Poor & Passing & $\begin{array}{l}\text { Me- } \\
\text { dium }\end{array}$ & Good & $\begin{array}{c}\text { Excel- } \\
\text { lent }\end{array}$ \\
\hline 01 & $\begin{array}{l}\text { Did the students participate } \\
\text { actively in the class? }\end{array}$ & & & & & \\
\hline 02 & $\begin{array}{l}\text { Was there sufficient } \\
\text { discussion among the } \\
\text { participants on the subject of } \\
\text { cuisine? }\end{array}$ & & & & & \\
\hline 03 & $\begin{array}{l}\text { Did the participants } \\
\text { understand the rules of the } \\
\text { educational game? }\end{array}$ & & & & & \\
\hline 04 & $\begin{array}{l}\text { Was the importance of } \\
\text { the kitchen for the culture } \\
\text { understood? }\end{array}$ & & & & & \\
\hline 05 & $\begin{array}{l}\text { Did you understand the } \\
\text { objectives of the lesson? }\end{array}$ & & & & & \\
\hline 06 & $\begin{array}{l}\text { Did the participants learn } \\
\text { the names of the foods in } \\
\text { Yaprakli? }\end{array}$ & & & & & \\
\hline 07 & $\begin{array}{l}\text { Were the participants able } \\
\text { to establish a connection } \\
\text { between the cuisine and } \\
\text { geographic location? }\end{array}$ & & & & & \\
\hline 08 & $\begin{array}{l}\text { Have various foods been } \\
\text { discussed sufficiently? }\end{array}$ & & & & & \\
\hline 09 & $\begin{array}{l}\text { Were the participants able to } \\
\text { write their own recipes? }\end{array}$ & & & & & \\
\hline 10 & $\begin{array}{l}\text { Did the participants } \\
\text { understand the dialogue and } \\
\text { the reading text? }\end{array}$ & & & & & \\
\hline
\end{tabular}




\section{CONCLUSION AND RECOMMENDATIONS}

At the beginning of this article, it was pointed out that foreign language teaching is an important part of the Turkish education system. Some state schools offer up to two foreign languages. At private schools, students have the opportunity to learn even more languages. Foreign language courses are offered at universities both as compulsory courses and as optional courses. Parents also attach great importance to learning foreign languages.

In this article, the subject of cuisine for active language teaching was tried out. At the beginning of this article, it was pointed out that the topic of cuisine is mentioned in daily newspapers, brochures, magazines, dictionaries, textbooks, and TV programs. Turkish students living in German-speaking countries, e.g., those who have been abroad within the Erasmus program, like to talk about the food in these countries. They compare the food in Turkey with other ones abroad. Foreign students studying in Turkey talk about their traditional dishes. The kitchen is an international theme because it can bring people from different cultures together. Irene Schumacher (2012) writes the following about the cookbook project in her media education practice blog:

- The intercultural cookbook, which was developed with women from different cultures, is very well received everywhere; the network character and the local connection are particularly pleasing.

- The recognition effect, knowing someone in the cookbook is one of the recipes for success of the soup cookbook.

After the project, women keep coming back to us asking whether they could contribute to the second cookbook. This second cookbook with a focus on souvenirs for the buffet is currently being created. Feedback from the women about what is special about the project is as follows:

Enjoyment of new challenges, motivation, with working and learning with others in a group promotes mutual respect and tolerance of other cultures, making contacts, having the courage to approach one another, we are different but one team, valuable integration work, a sign of diversity in Freiburg (Schumacher, 2012).

The Eifel community Netterheim in Germany justifies this Concept for the integration offer "Intercultural teaching kitchen Nettersheim" using the example of refugees as follows:

- Personal discussions are held about cooking and individual needs are identified.

- The visits show the special hospitality that is deeply anchored in the culture of many of our new residents.

- Traditionally, guests are warmly welcomed with tea, coffee, and biscuits.

- Eating together is based on the age-old custom of protecting guests and quenching thirst and hunger.

- Again and again the refugees prove their cooking skills and show us how important cooking and being together are to them.

- During our visits it regularly turns out that our new fellow citizens enjoy cooking together, like to share it with others, and are open to our local cuisine. 
- The exchange of different cultures helps to learn from one another.

- The exchange of different cultures creates awareness of the customs and habits of other cultures.

- The intercultural teaching kitchen offers excellent opportunities to promote the integration of refugees into our society.

- The intercultural teaching kitchen offers excellent opportunities to highlight the culinary cooking skills of the refugees.

- Refugees get to know German dishes, especially from the Eifel region, and learn more about our local culture in personal conversations (Eifelgemeinde Nettersheim (n.d., pp. 5-13).

The kitchen topic is an interdisciplinary issue. The issue of kitchen can be used to deal with topics such as nutrition, agriculture, animal husbandry, production, tourism, and trade.

\section{RECOMMENDATIONS FOR THE UNIT CUISINE}

The following suggestions are made based on the knowledge gained from the literature and lessons learned.

- Since the topic of cuisine interests both students and adults, the teaching unit should be expanded for further hours.

- The teaching unit should be enriched with different dialogues, reading texts, puzzles and exercise types.

- The learners should have the opportunity to report on their experiences both abroad and at

- home.

- The learners should have the opportunity to write their own recipes. At this point, reference is made to a publication by the DAAD (no year). This publication contains 30 recipes.

Each recipe contains the following information:

- Name of the dish, - Region, - Origin, - Ingredients, - Instructions and Tip.

- A version of this lesson is to be prepared for online teaching.

- Experiences with the kitchen unit should be exchanged with interested parties.

\section{REFERENCES}

[1] Aufderstraße, H., Bock, H., Gerdes, M., Müller, H., \& Müller, J. (1993). Themen Kurs 1, Lehrwerk für Deutsch als Fremdsprache. Huber: Max Hueber Verlag.

[2] Bakırcıoğlu, R. (2016). Ansiklopedik Eğitim ve Psikoloji Sözlüğ̈̈, Genişletilmiş 2 [Encyclopedic Dictionary of Education and Psychology, Extended 2]. Baskı, Ankara: Anı Yayıncilık.

[3] Coşkun, H. (Ed.) (2013). Otelcilik ve Turizm Alaninda Öğretim, Planlama, Uygulama ve Değerlendirme [Unterricht, Planung, Umsetzung und Evaluation im Hotelwesen und Tourismus/Teaching, Planning, Implementation and Evaluation in the Hotel Industry and Tourism]. Berlin: Dağyeli Verlag.

[4] Coşkun, H. (2018). Hoşgörü Eğitimi Bağlamında Bir Ders Planı Taslağının Geliştirilmsi ve Uygulamas1 [Development and Application of a Draft Lesson Plan in the Context of Tole- 
rance Education]. Çankır Karatekin Üniversitesi Karatekin Edebiyat Fakültesi Dergisi, 6(2), 1-26.

[5] Coşkun, H. (2020). Çankırı Yapraklı Yerel Gelişmeleri Araştırma Planı ve Eğitsel Uygulama Örnekleri [Forschungsplan über kommunale Entwicklung und Beispiele für die pädagogische Praxis/Research plan on community development and examples of educational practice]. Berlin: Konrad-Adenauer-Stiftung.

[6] Coşgun-Ögeyik, M. (2009). Evaluation of English Language Teaching Education Curriculum by Student Teachers. Insan ve Toplum, 9(1), 42-57.

[7] Demirezen, M. (2013). An Analysis of Turkish Coffee Culture and the Teaching of its Related Vocabulary Items. In: H. Coşkun (Ed.), Otelcilik ve Turizm Alanında Öğretim, Planlama, Uygulama ve Değerlendirme [Unterricht, Planung, Umsetzung und Evaluation im Hotelwesen und Tourismus/Teaching, Planning, Implementation and Evaluation in the Hotel Industry and Tourism] (pp. 327-343). Berlin: Dağyeli Verlag.

[8] Demiröz, A. (2017). Çankırı' da Sofra Adabı ve Yemek Kültürü [Table Manners and Food Culture in Çankır1]. Doğruyol Gazetesi. Retrieved August 31, 2020, from http://www.dogruyolgazetesi.com/cankiri-da-sofra-adabi-ve-yemek-kulturu/2674/

[9] Eifelgemeinde Nettersheim Konzept zum Integrationsangebot "Interkulturelle Lehrküche Nettersheim" [Concept for the Integration Offer "Intercultural Teaching Cuisine Nettersheim"]. Retrieved January 02, 2021, from https://kommunalwettbewerb-zusammenleben.de/sites/ default/files/konzept_interkulturelle_lehrkueche_nettersheim.pdf

[10] Ende, K., Grotjahn, R., Kleppin, K. \& Mohr, I. (2013). Curriculare Vorgaben und Unterrichtsplanung [Curricular Guidelines and Lesson Planning]. München: Langenscheidt, Goethe Institut \& Klett.

[11] Ersan, K. (2020). Yapraklı İlçesine Özgü Mutfak Kültürü. In: H. Coşkun (Ed.), Çankırı Yapraklı Yerel Gelişmeleri AraştırmaPlanı ve Eğitsel Uygulama Örnekleri [Research Plan on Communuty Development and Examples of Educational Practice] (pp. 262-273). Konrad-Adenauer-Stiftung: Berlin.

[12] Glowacka-Perlowska, E., Lipczynska, U., Ludwin, M., Luniewska, K., Pietrowska, M., Rozwalka, J., Szczepanska, U., Tworek U., Wasik, Z., \& Zagórna, M. (2007). einFach gut Deutsch für Alltag und Beruf, Band 1 [A subject good German for everyday life and occupation, Volume 1], Fraus \& Goethe Institut Inter Nationes: Bratislava.

[13] Häublein, G., \& Jenkins, R. (2008) Schlaumeier empfiehlt: Schul-Wortschatz Englisch komakt. Stuttgart: Ernst Klett Vertrieb.

[14] Hölscher, P., Piepho, H.-E., Roche, J., \& Simic, M. (2006). Handlungsorientierter Unterricht mit Lernzenarien - Kernfragen zum Spracherwerb. Oberursel: Finken Verlag.

[15] Huizinga, J. (2004). Homo Ludens: Vom Ursprung der Kultur im Spiel [From the origin oft the culture in the game]. H. Nachod (Übers.). 24. Aufl. Reinbek bei Hamburg: Rowohlt.

[16] Karabiyık, C. (2018). Designing a Sample Lesson Plan on the Topic of "Family" for Primary School Students. In: H. Coşkun (Ed.), Öğretmenlik Uygulaması ve Ders Planları [Fachpraktikum und Unterrichtspläne/Practice Teaching and Lesson Plans] (pp. 150-170). Berlin: Dağyeli Verlag.

[17] Kuş, E. (2007). Nicel-Nitel Araştırma Teknikleri [Quantitative-Qualitative Research Techniques]. Ankara: Anı Yayıncilık.

[18] Mitchell, H. Q. (2008). Traveller Beginners Student's Book. USA: MM Publications.

[19] Österreichisches Standarddeutsch (2014). Basiswörterbuch Türkisch - Deutsch/Deutsch-Türkisch Vokabeln und Phrasen für den Alltag [Basic Dictionary Turkish - German/German - Turkish Vocabulary and Phrases for Everyday Life]. Wien: Österreichischer Integrations Fonds.

[20] Parmentier, M. (2004). Spiel. In: D. Benner, J. Oelkers (Eds.), Historisches Wörterbuch der Pädagogik (pp. 929-945). Weinheim und Basel: Beltz.

[21] Roche, J. (2013). Fremdsprachenerwerb Fremdsprachendidaktik (3. Auflage). [Foreign Language Acquisition Foreign Language Didactics. 3. Edition]. Tübingen \& Basel: A. Franke Verlag.

[22] Schart, M. \& Legutke, M. (2012). Lehrkompetenz und Unterrichtsgestaltung. München: Langenscheidt \& Goethe Institut.

[23] Rösler, D. \& Würffel, N. (2017). Lernmaterialien und Medien. München: Langenscheidt, Goethe Institut \& Klett.

[24] Schumacher, I. (2012). Interkulturelles Kochbuch von und für Frauen. Medienpedagogik. Retrieved January 2, 2021, from https://www.medienpaedagogik-praxis.de/2012/11/28/ 
interkulturelles-kochbuch-von-und-fur-frauen/

[25] Şeker, H. (2014). Eğitimde Program Geliştirme - Kavralar Yaklaşımlar [Curriculum Development in Education - Concepts and Approaches]. Ankara: Anı Yayıncilık.

[26] Wehmeier, S., Dralle, A., \& Thiergart, M. (2015). Travel Phrase Book. German. The right word at the right time. Pons: Stuttgart.

[27] Yıldırım, A., \& Şimşek, H. (2008). Sosyal bilimlerde nitel Araştırma yöntemleri [Qualitative research methods in social sciences]. Ankara: Seçkin Yayıncilık.

[28] Yorganc1, N., \& Keskil, G. (2008). English for Tourism. Vocational Schools of Hospitality and Tourism, Ankara: Gündüz Eğitim ve Yayıncılık. 


\section{ANNEX}

\section{Questions to the dialogue}

1. Who has a homework about local cuisine in the dialogue?

( ) a. Mert () b. Buğra ( ) c. Tattiana () d. Father ( ) e. Mother

2. Which is one of Yapraklı's local desserts?

() a. wheat semolina ( ) b. Yaren's shallow braising pan casserole ( ) c. Walnut pâté

( ) d. flour halva( ) e. thin bread amulet

3. What is the most important thing that gives flavor to foods in Yapraklı?

( ) a. sugar ( ) b. butter ( ) c. Rock salt ( ) d. Spice ( ) e. thyme

4. What is the famous sorbet Tattiana's father said?

( ) a. Rose hips ( ) b. Cornelian ( ) c. hawthorn ( ) d. Sumac ( ) e. Orange

5. What local soup did the grandmother say?

( ) a. Lens ( ) b. Chicken ( ) c. Wheat ( ) d. Vegetables ( ) e. Tarhana

Answers to the question on dialogue text (Answer Key)

\begin{tabular}{lllll}
\hline 1 & 2 & 3 & 4 & 5 \\
\hline $\mathrm{c}$ & $\mathrm{d}$ & $\mathrm{C}$ & $\mathrm{b}$ & $\mathrm{e}$ \\
\hline
\end{tabular}

Questions to the reading text

1. In which region is more animal protein used in meals?

( ) a. Marmara ( ) b. Aegean Sea ( ) c. Mediterranean ( ) d. Central Anatolia ( )

e. Eastern Anatolia

2. Which of the following information is correct?

( ) a. Local foods are not healthy.

( ) b. Local foods are not very tasty. 
( ) c. Local foods have a high nutritional value.

( ) D. Local food is quite expensive.

( ) e. Local foods cause health problems.

3. In which region are wheat, pulses, and meat consumed together?

( ) a. Eastern Anatolia Region ( ) b. Central Anatolia Region ( ) c. the Mediterranean

( ) D. Southeast Anatolia Region ( ) e. Aegean region

4. What is not a meal in Central Anatolia?

( ) a. Meat casseroles ( ) b. Olive oil artichoke ( ) c. Coarse dough

( ) D. Wheat soup ( ) e. Write rolls

5. What is not a meal from Eastern Anatolia?

() a. Stuffed cabbage () b. Double zucchini flower () c. lahmacun

( ) D. Roasted Green Beans ～( ) e. walnut pâté

Answers to the questions of the reading text (Answer Key)

\begin{tabular}{lllll}
\hline 1 & 2 & 3 & 4 & 5 \\
\hline $\mathrm{e}$ & $\mathrm{c}$ & $\mathrm{B}$ & $\mathrm{b}$ & $\mathrm{c}$ \\
\hline
\end{tabular}

\section{Baking recipe for the apple cake}

\begin{tabular}{|c|c|c|}
\hline Elmalı Pasta Tarifi & $\begin{array}{l}\text { Backrezept für den } \\
\text { Apfelkuchen }\end{array}$ & $\begin{array}{l}\text { Baking recipe for the apple } \\
\text { cake }\end{array}$ \\
\hline $\begin{array}{l}\text { Burada bir elmalı pasta (kek) } \\
\text { tarifi } \\
\text { yer almaktadır. Bu taslağı } \\
\text { yemek } \\
\text { tarifleri için de } \\
\text { kullanabilirsiniz. } \\
\text { Elmalı kek yapma } \\
\text { tarifi aşağıdaki bilgileri } \\
\text { içermektedir: } \\
\text { Pastanın adı: Apfelkuchen } \\
\text { (Elmalı kek) }\end{array}$ & $\begin{array}{l}\text { Hier finden Sie ein Backrezept } \\
\text { für Apfelkuchen. Diesen } \\
\text { Entwurf können Sie auch für } \\
\text { Kochrezepte verwenden. Das } \\
\text { Backrezept für Apfelkuchen } \\
\text { enthält folgende Angaben: } \\
\text { Name des Kuchens: } \\
\text { Apfelkuchen }\end{array}$ & $\begin{array}{l}\text { Here you will find a baking } \\
\text { recipe for apple cake. You can } \\
\text { also use this draft for cooking } \\
\text { recipes. The baking recipe for } \\
\text { an apple cake contains the } \\
\text { following information: } \\
\text { Name of the cake: } \\
\text { Apfelkuchen (apple cake) }\end{array}$ \\
\hline
\end{tabular}


Journal of Education Culture and Society No. 1_2021

\begin{tabular}{|c|c|}
\hline Yöre & Region \\
\hline Kuzey Denizi kıyısındaki & Die Region „altes Land“ an \\
\hline "eski bölge" asırlık meşhur & der Nordseeküste hat eine \\
\hline meyve yetiştirme geleneğine & berühmte, jahrhundertealte \\
\hline sahiptir. Bugün bile Elbe & Obstbautradition. \\
\hline 1rmağı üzerinde bulunan & Die pulsierende Metropole \\
\hline Hamburg metropolü & Hamburg an der Elbe \\
\hline içtenlikle "meyve bahçesi & wird bis heute liebevoll als \\
\hline olarak adlandırılmaktadır. & „Obstgarten“ bezeichnet. \\
\hline Bölgenin verimli lığlı arazide & Der mit Nährstoffen gefüllte \\
\hline sulu elmalı kek için en iyi & Marschlandboden der Region \\
\hline meyve üretilmektedir & $\begin{array}{l}\text { bringt die besten Früchte für } \\
\text { einen saftigen Apfelkuchen } \\
\text { hervor. }\end{array}$ \\
\hline
\end{tabular}

Kaynağı
Elmalı kek Almanya
genelinde popülerdir,
ancak hazırlama yöntemleri
bölgeden bölgeye farklılık
gösterir. Pastacı bazen elma
dolgusuna kuru üzüm ya da
badem ekler.

Ursprung

Ursprung

Apfelkuchen ist in ganz

Deutschland beliebt, obwohl

die Zubereitungsmethoden

von Region zu Region

unterschiedlich sind.

Manchmal fügt der Konditor

der Apfelfüllung Rosinen

oder Mandeln hinzu.

Malzemeler
120 gr donmamış tereyağı,
140 gr şeker, 1 paket vanilya
şekeri (8 gr), 3 yumurta, 200
gr un, 1 çay kaşı ğ kabartma
tozu, 4-5 ekşi elma.

\section{Zutaten}

$120 \mathrm{~g}$ weiche Butter, 140

g Zucker, 1 Packung

Vanillezucker (8 g), 3 Eier,

$200 \mathrm{~g}$ Mehl, 1 TL Backpulver, 4-5 saure Äpfel.

Yapılışı

Anweisungen

* Sahne und die Butter in

einem Mixer.

krema haline getirin.

* Şekeri yavaş yavaş ekleyin

ve yumurtaları karışım hafif

olana ve kabarana kadar

karıştırmaya devam edin.

* Un ve kabartma tozunu

karıştırıp tereyağı ve şeker

karışımına ekleyin.

* Kek karışımını tereyağı

ile yağlanmış yaylı bir kek

kalıbına koyun ve düzleştirin. mit

* Elmaları soyun,

çekirdeklerini çıkarın ve

dörde bölün.

* Fügen Sie nach und nach

den Zucker und die Eier

hinzu und mischen Sie

weiter, bis die Mischung

leicht und locker ist.

* Mehl und Backpulver

mischen und zur Butter-

Zucker-Mischung geben.

Die Kuchenmischung in eine

* Butter gefettete Springform

geben und glatt streichen.

* Die Äpfel schälen

* Elma dilimlerinin arkasında entkernen und vierteln.

birkaç yarık açın ve bunları

karışımın üzerine yarıklar

yukarı bakacak şekilde

yerleştirin.

* Keki $180^{\circ} \mathrm{C}^{\prime}$ de yaklaşı 40

* Schneiden Sie mehrere

Schlitze auf der Rückseite der

Apfelviertel und legen Sie sie mit den Schlitzen nach oben

auf die Mischung.

* Backen Sie den Kuchen bei

Region

The "old country" region

along the North Sea coast

has famous, centuries-old

fruit growing tradition.

Even today, the pulsating

metropolis of Hamburg

on the River Elbe is

affectionately called the

"fruit garden." The region's

nutrient-filled marshland soil

produces the very best fruit

for a juicy apple cake.

\section{Origin}

Apple cake is popular

throughout Germany, though

preparation methods do

vary from region to region.

Sometimes, the Confectioner

will add raisins or almonds to the apple filling.

dakika pişirin.

180

${ }^{*}$ C für ca. 40 Minuten.

\begin{tabular}{lll}
\hline İpucu & Tipp & Tip \\
Pudra şekeri serpin ve & Mit Puderzucker bestäuben & $\begin{array}{l}\text { Dust with icing sugar and } \\
\text { çırpılmış krema ile servis }\end{array}$ \\
$\begin{array}{l}\text { und mit Schlagsahne } \\
\text { servieren. }\end{array}$ & \\
\hline
\end{tabular}

\section{Ingredients}

$120 \mathrm{~g}$ soft butter, $140 \mathrm{~g}$ sugar,

1 pack of vanilla sugar $(8 \mathrm{~g})$,

3 eggs, $200 \mathrm{~g}$ flour, 1 level

tsp baking powder, 4-5 sour apples.

\section{Instructions}

* Cream and the butter in a

blender.

* Gradually add the sugar

and eggs continue mixing

until the mixture is light and

fluffy.

* Combine the flour and

baking powder and add it to the butter and sugar mixture.

* Put the cake mixture into a spring-release baking tin that has been greased with butter and smooth it flat.

*Peel, core and quarter the apples.

* Cut several slits on the back of the apple quarters and

place them on the mixture with the slits pointing up. * Bake the coke at 180 for around 40 minutes. servieren. 